\title{
MICROBIOLOGICAL INDICATORS AND HEAVY METAL CONCENTRATION IN ECOLOGICAL ASSESSMENT OF URBAN SOILS OF SAINT PETERSBURG, RUSSIA
}

\begin{abstract}
This paper aimed to characterize urbostratozems (Urbic Technosol, WRB) of Saint Petersburg located in industrial ("Electrodepo" railway station) and residential (region Polish Garden) zones. These soils were also compared with background (natural) soddy podzol soil (Umbric Albic Gleic Podzol, WRB) sampled in recreational zone (suburban park "Oranienbaum"). Soil samples were collected from soil horizons for chemical analysis and from top of soils for microbialogical analysis in June of 2012. Chemical properties ( $\mathrm{pH}$, total organic carbon, mobile forms of Kand P) and content of heavy metals (Pb, Cu, Zn, Ni) in soils were determined. Culturable forms of microorganisms (bacteria and fungi) were studied. Assessment of the enzymatic activity of the soil was carried out by culturing of microorganisms-producers of protease, amylase, cellulase and lipase on special media. Biotesting using cress (Lepidium sativum L.) seeds had been carried out for assessment of soil phytotoxicity. It was found that chemical properties of urban and natural soils differ greatly. Heavy metal pollution was evident in both urban soils, but maximum concentrations of heavy metals were found in the soil of the industrial zone. Phytotoxocity had been also most pronouncend in the soil of the industrial zone. The natural soil exhibited significantly higher respiration activity than urbostratozems. The greatest difference in the structure of the bacterial and fungal communities was observed between the natural soil of the recreational zone and the urbostratozem of the industrial zone. Algae had been present in the urban soils of the residential zone that was not observed in the natural podzol. The minimum number of producers of all enzymes, except for cellulase, was observed in the soddy podzol in the recreational zone. The maximum number of protease and amylase producers was found in the soil of the industrial zone. Lipolytic activity was almost the same in all samples. It was found that more sensitive biological methods are needed for environmental assessment of urban soils. The results of the article can be used by soil scientists and environmental engineers for a comprehensive environmental assessment of the condition of urban soils and for creating new urban green spaces.
\end{abstract}

KEY WORDS: urban soil, heavy metal, microbiological indicator, enzyme activity, soil phytotoxocity

CITATION: Natalia N. Matinian, Anastasia L. Gusareva, Kseniia A. Bakhmatova, Anastasia A. Sheshukova (2019). Microbiological Indicators And Heavy Metal Concentration In Ecological Assessment Of Urban Soils Of Saint Petersburg, Russia. Geography, Environment, Sustainability, Vol.13, No 1, p. 214-223 DOl-10.24057/2071-9388-2019-63

\section{INTRODUCTION}

Urbanization significantly influenced the environment and results in irreversible changes of relief, hydrological conditions, vegetation cover and soils. Soils in urban environment are characterized by the presence of many artefacts, alkaline $\mathrm{pH}$, high content of organic carbon and nutrients, as well as high content of technogenic contaminants (Lehmann and Stahr2007; Burghardt et al. 2015). Also typical for urban soils is spatial heterogeneity of structure and properties (Greinert 2015). According WRB (IUSS Working group WRB 2006, 2014), the most of urban soils belong to the Technosols group, with different qualifiers, used to represent their diversity (Charzynski et al. 2013). The morphological and chemical features of these soils reflect the history of land use of each particular urban area (Prokofieva and Poputnikov 2010). The direction of pedogenesis in urban environment also depends on characteristics of soil forming material and climate (Aleksandrovskiy et al. 2012). Biological properties of urban soils can serve as indicators of their ecosystem function (Piotrowska-Dlugosz and Charzyńsky 2015), with the microbial diversity and activity being among the most meaningful biological characteristic of soils (Schindelbeck et al. 2008; Terekhova et al. 2014; Rozanova et al. 2016). Microbial properties (including substrate-induced and basal respiration) are influenced by specific chemical properties in dif- ferent functional zones of city (Ivashchenko et al. 2019). The main groups of soil microorganisms include bacteria, fungi, actinomycetes and algae. Content of organic matter, texture and redox potential determine the profile distribution of microorganisms in natural soils (Marfenina 1987, 2005). Despite the wide using molecular techniques in modern studies (Bouchez et al. 2016; Huot et al. 2017), cultivation of microorganisms is considered a useful tool for investigation of urban soil communities (Braun et al. 2006; Marfenina et al. 2017).

Heavy metals (HM) are one of the most dangerous pollutants of urban soils, reducing their biological activity and productivity (Yungen et al. 2001; Papa et al. 2010; Muhlbachova et al. 2015). Elevated concentaration of HM reported to reduce microbial diversity (Jieng et al. 2010). The urgency of this problem is underlined by the impact of HM on soil microorganisms, which play a key role in soil processes, required for viable ecosystem (Nannipiery et al. 2003). The scope of toxic effects due to HM is determined by the nature of the HM, the form of the compounds in question, soil $\mathrm{pH}$, and the the specific sensitivity of different microorganisms. Parameters of biodiversity and physiological activity of soil microbiota (Yuangen et al. 2006; Niemeyer et al. 2012), fungal diversity of soil (Marfenina et al. 2017), as well as the species composition and amount of soil algae can be used as biological indicators of soil contamination with HM (Zenova et al. 1995). 
The sharp decrease in the activity of enzymes: amylase, dehydrogenase, urease, invertase, catalase was previously observed in soil with the influence of elevated HM concentrations (Zhigareva et al. 2006). Restructuring of the microbiocenosis had been found in the soil containing heavy metals in concentrations of 1-2 orders of magnitude higher than the background. A decrease in richness and diversity of soil micromycetes species was also observed, with few, down to a single one species dominating. The number of colored micromycetes increased and in some cases, toxin-forming microorganisms and resistant species dominated in such contaminated soils (Zvyagintsev et al. 2005). The effect of HM on enzyme activities of soil depends on soil organic matter content (Stefanowicz et al. 2010; Calvarro et al. 2014; Muhlbachova et al. 2015). It was shown that in soils that poor in nutrients, micromycetes are more susceptible to the negative effects of HM. It was reported that HM inhibit the metabolism of microorganisms, change their growth kinetics and morphology. A catastrophic decrease of soil microbiological activity or total death of microorganisms was found at concentrations of heavy metals of 4 and more orders of magnitude above the background (Rabotnova and Pozmogova 1979). However, Hagmann et al. (2015) showed that the highest activities of several enzymes (alkaline phosphatase, celobiohydrolase, L-leucine-aminopeptidase) were positively correlated with the highest HM contamination of soil.

Ammonifying bacteria, along with some spore bacteria, cellulolytic bacteria and actinomycetes are most sensitive to soil pollution. However, some authors reported increase of bacterial numbers in the most anthropogenically transformed soils along with decrease of their enzymatic activity (Naylo et al. 2019). An increase in the total number of microflora has been found in the soils with increased content of HM (Castaldi et al. 2004). Active development of resistant forms had been observed possibly due to the absence of competition as more sensitive microorganisms did not survive in the environment. Marfenina (2005) reported the increase of soil microfungae diversity in urban environment in comparison with zonal conditions. On the other hand, several heavy metals (e.g., Cu, Zn, Mo) are known to be micronutrients which can stimulate the microbial growth.

The aims of this paper were to study morphological and chemical properties of urban soils and to find easily identifiable biological indicators for environmental assessment of soils of different types of urban land use. Such indicators are in demand by environmental practitioners, limited in material resources and specialized laboratory equipment. It is known that modern molecular genetic methods for studying soil biota require high material costs and the availability of high-tech analytical equipment.

\section{MATERIALS AND METHODS}

Saint Petersburg is located in the northwestern part of Russia $\left(59^{\circ} 57^{\prime} \mathrm{N}, 30^{\circ} 19^{\prime} \mathrm{E}\right)$ on the banks of the river Neva and the east coast of the Finnish gulf. The climate of humid continental type, the average annual temperature of $5.8^{\circ} \mathrm{C}$ and the average annual precipitation of about $660 \mathrm{~mm}$. There are several main functional areas on the territory of the city: residential, industrial, agricultural, recreation. The working hypothesis of the study was that there is a direct relationship between the type of land use, the level of pollution and biological indicators.

The soils of the following zones were selected for the study: 1. Recreation zone (the State Art and Architectural Palace and Park Museum-Reserve "Oranienbaum"; area - 165 ha) - profile 1. Research site vegetation - coniferous forest with ground cover of bilberry and green moss.
2. Residential zone (central part of the city, Polish Garden is located inside residential areas with dense buildings, between the Fontanka embankment, Izmailovsky avenue, Derzhvinsky lane and $1^{\text {st }}$ Krasnoarmeisky street; area -2.3 ha) - profile 2. The inner garden of the former G.R. Derzhavin manor was choosen to characterize the soil of residential zone, because it is difficult to find green space in the historical center of Saint Petersburg. Research site vegetation-grassy lawn.

3. Industrial zone (railway station Elektrodepo, near electromechanical workshops) - profile 3. Research site vegetation -ruderal herbaceous plants.

Soil names and indexes of natural soil horizons were given according to Classification System of Russian Soils (2004) and WRB (IUSS Working group WRB 2014). Diagnostics of urban soils was made according to Prokof'eva et al. (2014).

Samples for chemical analysis were taken from each horizon of soil profiles, then air-dried and sieved ( $1 \mathrm{~mm})$. Traditional analytical methods were used to obtain physical and chemical characteristics of soils (Vorobieva 2006). Total organic carbon (TOC) content was determined titrimetrically by dichromate oxidation, $\mathrm{pH}$ was measured in suspension at a ratio of soil to water $=1: 2.5$; the content of plant available potassium (K) and phosphorus ( $\mathrm{P}$ ) compounds in soils with $\mathrm{pH}>7$ - using a $1 \%$ solution of $\left(\mathrm{NH}_{4}\right)_{2} \mathrm{CO}_{3}$ (ratio soil to solution $=1: 20$ ), in soils with $\mathrm{pH}<7-$ using $0,2 \mathrm{~N}$ solution of $\mathrm{HCl}$ (ratio soil to solution = 1:5). P was measured photometrically (FEK-3) in an extract tinged with ammonium-heptamolybdate and ascorbic acid reagent. Potassium was determined by photoelectric flame photometry. The content of mobile forms of phosphorus and potassium was estimated using the benchmarks designed for agriculture plants. Heavy metal (HM) total concentrations, namely of $\mathrm{Cu}, \mathrm{Pb}, \mathrm{Zn}$, Ni were determined by atomic emission spectroscopy (AES). Digestion of samples was carried out by evaporation from the carbon electrode channel (GOST 4108-265-04 2004; Vorobieva 2006). The analysis was done at the Central laboratory of A.P. Karpinsky Russian Geological research institute (Saint Petersburg) (included in the International Association of Geoanalysts - IAG).

Soil samples (1 mixed sample consisted of 5 subsamples from each site) for microbiological analysis were collected in the upper $10 \mathrm{~cm}$ of soil profile and analysed immediately after sampling. The following methods were used to determine the biological properties of the soil (Zvyagintsev 1991; Labutova 2008; Labutova and Bankina 2013): 1. The biological activity of soils in respiration (actual, potential) was determined by the modified Golovko method, based on producing of $\mathrm{CO}_{2}$ under laboratory conditions. To determine the amount of actual soil respiration, a sample of soil in a small Petri dish was placed in a hermetically sealed container next to a cup with $20 \mathrm{ml}$ of $0.02 \mathrm{~N} \mathrm{NaOH}$. The sample was left for a day and then the amount of $\mathrm{CO}_{2}$ released per day and bound by $\mathrm{NaOH}$ was determined titrimetrically (0.02 $\mathrm{N} \mathrm{H}_{2} \mathrm{SO}_{4}$, phenolphthalein). A nutrient substrate (10\% glucose solution) was preliminarily added to the soil sample to determine potential respiration.

2. The number and diversity of bacteria was determined by spreading on meat-peptone agar (MPA) media. Desorption of microorganisms was carried out with $0.1 \%$ solution of $\mathrm{Na}_{2} \mathrm{P}_{2} \mathrm{O}_{7}$ (Szegi 1983), then soil suspension was shaken for 10 minutes on laboratory shaker and settled. A series of 10fold dilutions of soil sample was prepared. Determination of fungi was carried out on the Czapek medium. Inhibition of bacterial growth during the isolation of fungi was carried out by adding streptomycin sulfate (50 mg /l) (Microbiology laboratory manual 2005). Plating was performed in 5 replications per variant. The numbers of colonies formed 
on the medium were counted after the end of the incubation period: 3 days for bacteria, and 5-7 days for fungi. Cultivation have been done at a temperature of $28^{\circ} \mathrm{C}$. Variety of soil bacteria and fungi was evaluated using MCT, a number of Morpho-Cultural Types, representing a number of species of soil fungi and bacteria in the sample which correlated to numbers of colonies with the same characteristics formed by a single type of microorganism. The frequency of occurrence of MCT (\%) was counted as n.100/N, where $n$ - the number of plates where this MCT was found and $\mathrm{N}$ - the total number of plates. The abundance of MCT (\%) was conted as a.100/A, where a - the number of colonies of this MCT, A -the total number of colonies (Labutova 2009). According to values of abundance and frequency MCT were assessed as dominant (25-30\% and more), common (15-25\%), rare (5-15\%), random (less than 5\%).

3. The number of soil algae was determined by sowing on Gromov's agar medium (№1). Soil particles were placed on the surface of agar medium and cultivated at a temperature of $24^{\circ} \mathrm{C}$, illuminated with fluorescent lamps, for 30 days.

4. Assessment of the enzymatic activity of the soil was carried out by culturing of microorganisms-producers of protease, amylase, cellulase and lipase on special media. This method shows potential biological activity since during the cultivation of microorganisms in laboratory conditions, the share of them which were active in real soil remains unknown. However, this potential activity differs across different soil types (Zvyagintsev et al. 2005). The soils a series of 10 -fold dilutions of soil sample was prepared, with 3 replications per variant, and incubation time of 3-5 days:

1) Milk agar was used to determine the protease activity of the soil. The method is based on the ability of protease producers to break up milk protein (casein). $0.5 \mathrm{ml}$ aliquots of soil suspension were placed on the medium. The milk agar has cleared around the colonies of microorganisms which were considered active protease producers. Microorganisms that formed colonies, but did not produce cleared zones, were defined as having a weak protease activity.

2) Starch-ammonium agar was used to determine the amylolytic activity. Then the surface of the agar was covered with Lugol's solution and the total number of colonies was counted. The activity and the number of producers of amylase were determined depending on the stained areas around the colonies. The activity of amylase producers (very active and active producers) was evaluated by the comparison of the diameters of the hydrolysis zones from the edge of the colonies. Microorganisms that formed colonies, but did not produce the hydrolysis zones, were defined as having a weak amylase activity.

3) To determine the cellulolytic activity of the soil, Getchinson's agar medium was used. Filter paper was placed on the surface of the medium and $1 \mathrm{ml}$ of soil suspension was applied evenly. The number of colonies exhibited cellulose decomposed around them was determined after 2-week incubating at $28^{\circ} \mathrm{C}$. The method is based on the ability of the producers of cellulases to use cellulose of filter paper as the sole carbon source.

4) Lipolytic activity of the soil was determined using agar medium with castor oil. Small soil agregates (20 pieces) were placed in each dish and incubated for 3-5 days. The numbers of agregates exhibited opaque zones around them were counted. The method is based on the fact that fat decomposition occurs in the presence of lipases and free fatty acids accumulate in the medium, causing its opaqness.

5. Cress (Lepidium sativum L.) seeds were used for assessment of the soil phytotoxicity.

Phytotoxicity of the soil was measured by the difference in the number of germinated seeds and the length of seedlings and roots in the studied soil and in the control (wet filter paper) in triplicate. The duration of the growh was 5-7 days.

Statistical data processing was carried out using STATISTICA 10.0.

\section{RESULTS AND DISCUSSION}

Gleyed soddy podzol (Umbric Albic Gleic Podzol, WRB) on glacio-lacustrine sands (profile 1) has well defined diagnostic horizons: AY-AYe-E-BF-BCg-Cg. Water appeared from the depth of $82 \mathrm{~cm}$. The soil meets the characteristics of the zonal type. Profile 2 exhibited urbostratozem (Urbic Technosol, WRB) on buried gray-humus gley soil (Umbric Gleysol, WRB) consisted of several filled-in horizons and underlyed by gray-humus alluvial soil (UR1ay-UR2-UR3rt-UR4-UR5rtUR6-UR7-[AY]-CG). The garden planning had been changed several times; the filling and leveling of the surface were carried out. The thickness of stratified humus-accumulative horizons was $30 \mathrm{~cm}$. The soil profile was characterized by a series of infilled layers of different color, thickness, and composition. Anthropogenic material consisted mainly of construction and household waste (fragments of bricks, ceramics, pieces of asphalt, broken glass, coal, bones, pieces of tin, wire, nails, wood, etc.). It was mixed with sandy or loamy-sandy fine earth material. Some anthropogenic layers contained organic matter, which allows suggest that the filling of humus-enriched material (e.g. compost) and the terrain levelling were done repeatedly. The total thickness of the cultural layer was $155 \mathrm{~cm}$. At a depth of $155 \mathrm{~cm}$, a dark gray homogeneous humus horizon of buried natural soil was found. Profile 3 - Technogenic urbostratozem on technogenic material (Urbic Technosol, WRB) (profile 3) consisted of infilled layers (thickness $60 \mathrm{~cm}$ ). The soil characterized by loamy-sandy and sandy texture and the significant amount of artefacts (granite rubble, broken glass, pieces of metal, polyethylene, textile fragments etc.). At a depth of $60 \mathrm{~cm}$ was a concrete block.

Soddy podzol (profile 1) had low pH value (3.5-4.1) (Table 1). Urbostratozem (profile 2) characterized by slightly acid reaction of upper horizons (6.0-6.2), which increases with depth up to $\mathrm{pH}=8.4$. The soil alkalinization was likely caused by the release of calcium from various construction debris (e.g. cement, bricks, etc.). Lime layer was found at a depth of 112-124 cm. Technogenic urbostratozem (profile 3) has slightly acid and near neutral pH (6.2-6.8).

Organic carbon content in soddy podzol is low and decreased with depth (from 1.8 to $0.32 \%$ ), demonstrating ordinary distribution for this soil type. The carbon content in the soil of the Polish Garden (profile 2) varied greatly throughout the profile, due to the abundance of anthropogenic inclusions and differences in the composition and origin of anthropogenic layers. In the soil of the industrial zone (profile 3), the carbon content varies from 1.4 to $4.7 \%$, which also depended on the origin of the anthropogenic material.

The studied soils had a low content of exchangeable potassium, which can be explained by their light texture. The amount of mobile forms of phosphorus in the natural soil (profile 1) was medium. The sufficiency of mobile phosphourus in the urban soils (profiles 2 and 3) was estimated as high to very high. This enrichment with $P$ is likely caused by the presence of household waste in the soils.

Heavy metals content. The main inorganic pollutants on the urban and suburban territory were $\mathrm{Cu}, \mathrm{Pb}, \mathrm{Zn}, \mathrm{Ni}$. HM content in the soils presented in Table 2.

The content of HM in the soil of the recreation zone (pro- 
Table 1. Chemical properties of soils

\begin{tabular}{|c|c|c|c|c|c|}
\hline \multirow{2}{*}{ Horizon } & \multirow{2}{*}{$\begin{array}{c}\text { Depth, } \\
\mathrm{cm}\end{array}$} & \multirow{2}{*}{$\begin{array}{l}\mathrm{pH} \\
\mathrm{H}_{2} \mathrm{O}\end{array}$} & \multirow{2}{*}{$\begin{array}{c}\text { TOC, } \\
\%\end{array}$} & $\mathrm{P}_{2} \mathrm{O}_{5}$ & $\mathrm{~K}_{2} \mathrm{O}$ \\
\hline & & & & \multicolumn{2}{|c|}{$\mathrm{mg} / \mathrm{kg}$} \\
\hline \multicolumn{6}{|c|}{ P.1 Gleyed soddy podzol (Umbric Albic Gleic Podzol) } \\
\hline AY & $2-17$ & 4.0 & 1.81 & 90 & 37 \\
\hline AYe & $17-30$ & 3.5 & 0.90 & 100 & 14 \\
\hline E & $25-30$ & 4.1 & 0.42 & 85 & 1 \\
\hline $\mathrm{BF}$ & $30-44$ & 3.6 & 1.31 & 84 & 2 \\
\hline $\mathrm{BCg}$ & $44-82$ & 3.9 & 0.33 & 186 & 1 \\
\hline $\mathrm{Cg}$ & $82-94$ & 4.3 & 0.32 & 96 & 1 \\
\hline \multicolumn{6}{|c|}{ P.2 Urbostratozem (Urbic Technosol) on buried gray-humus gley soil (Umbric Gleysol) } \\
\hline UR1ay & $3-15$ & 6.0 & 3.83 & 181 & 32 \\
\hline UR2 & $20-30$ & 6.2 & 2.64 & 98 & 40 \\
\hline UR2 & $30-47$ & 7.8 & 3.11 & 168 & 78 \\
\hline UR3rt & $47-60$ & 7.9 & 6.91 & 156 & 67 \\
\hline UR4 & $60-99$ & 8.2 & 2.63 & 151 & 20 \\
\hline UR5rt & $99-112$ & 8.3 & 5.22 & 145 & 53 \\
\hline UR6 & $124-140$ & 8.4 & 4.48 & 132 & 38 \\
\hline UR7 & $140-155$ & 8.1 & 2.85 & n.d.* & n.d. \\
\hline$[\mathrm{AY}]$ & $155-171$ & 7.7 & 1.93 & 105 & 90 \\
\hline$C G$ & $171-176$ & 8.2 & 0.51 & n.d. & n.d. \\
\hline \multicolumn{6}{|c|}{ P.3 Technogenic urbostratozem (Urbic Technosol) } \\
\hline UR1 & $2-19$ & 6.5 & 4.71 & 164 & 63 \\
\hline UR2 & $19-22$ & 6.4 & 1.45 & 153 & 23 \\
\hline UR3 & $22-28$ & 6.6 & 3.44 & 113 & 42 \\
\hline $\mathrm{TCH}$ & $28-30$ & 6.2 & 3.93 & 121 & 18 \\
\hline UR4 & $30-60$ & 6.9 & 4.31 & 280 & 35 \\
\hline
\end{tabular}

${ }^{*}$ n.d. - no data

Table 2. Heavy metal concentration in soils, $\mathrm{mg} / \mathrm{kg}$

\begin{tabular}{|c|c|c|c|c|c|}
\hline Horizon & Depth, cm & $\mathrm{Zn}$ & $\mathrm{Pb}$ & $\mathrm{Cu}$ & $\mathrm{Ni}$ \\
\hline \multicolumn{6}{|c|}{ P.1 Gleyed soddy podzol (Umbric Albic Gleic Podzol) } \\
\hline AY & $2-7$ & 13 & 26 & 11 & 13 \\
\hline AY & $7-17$ & 14 & 14 & 5 & 11 \\
\hline AYe & $17-30$ & 14 & 15 & 4 & 8 \\
\hline \multicolumn{6}{|c|}{ P.2 Urbostratozem (Urbic Technosol) on buried gray-humus gley soil (Umbric Gleysol) } \\
\hline UR1ay & $3-15$ & 178 & 46 & 29 & 18 \\
\hline UR2 & $20-30$ & 179 & 55 & 43 & 19 \\
\hline UR2 & $30-47$ & 120 & 100 & 30 & 12 \\
\hline
\end{tabular}




\begin{tabular}{|c|c|c|c|c|c|}
\hline UR3rt & $47-60$ & 80 & 150 & 30 & 10 \\
\hline UR4 & $60-99$ & 80 & 60 & 25 & 8 \\
\hline UR5rt & $99-112$ & 80 & 100 & 25 & 10 \\
\hline UR6 & $124-140$ & 60 & 50 & 20 & 8 \\
\hline UR7 & $140-155$ & 50 & 20 & 20 & 12 \\
\hline$[\mathrm{AY}]$ & $155-171$ & 40 & 20 & 50 & 12 \\
\hline CG & $171-176$ & 30 & 20 & 2 & 12 \\
\hline \multicolumn{6}{|c|}{ P.3 Technogenic urbostratozem (Urbic Technosol) } \\
\hline UR1 & $2-19$ & 244 & 64 & 84 & 38 \\
\hline UR2 & $19-22$ & 40 & 18 & 24 & 11 \\
\hline UR3 & $22-28$ & 73 & 35 & 44 & 20 \\
\hline $\mathrm{TCH}$ & $28-30$ & 211 & 77 & 168 & 45 \\
\hline UR4 & $30-60$ & 202 & 70 & 160 & 33 \\
\hline \multicolumn{2}{|c|}{$\begin{array}{c}\text { Approximate permissible concentrations } \\
\text { (APC), mg/kg (HN 2.1.7.2511-09) }\end{array}$} & 55 & 32 & 33 & 20 \\
\hline \multicolumn{2}{|c|}{ Background values* } & 51 & 16 & 15 & 11 \\
\hline
\end{tabular}

*Median value for sandy and loamy-sandy soils of North-West Russia, humus horizon (Matinian et al. 2007)

**The values exceeding the APC are in bold

file 1) corresponded to the background level, excluding Zn. The $\mathrm{Zn}$ content in this profile substantially lower than the background level. This phenomenon could be explained by genesis and chemical composition of the soil forming material (limnoglacial sands which are depleted in many elements). The content of HM in urbostratozems (profiles 2 and 3) significantly exceeded background values, not only in the upper horizons, but also in the middle and lower parts of the profile. The HM pollution was associated with the presence of anthropogenic material in soil horizons. The HM concentrations exceeding the allowed levels were found in both upper and lower parts of profile of the industrial zone soil. Technogenic urbostratozem was characterized by high content of copper ( 5 times higher than the value of the APC) and nickel (2 times higher than the value of the APC), which was not observed in the urban soil of the residential zone. Most likely, this type of pollution is associated with trains'repair and maintenance. The profile distribution of total HM concentrations in urbostratozems mainly depends on the composition of bulk layers and the level of anthropogenic impact at different stages of the soil formation.

Soil respiration. The actual respiration of the upper horizons of the studied soils was $3-6 \mathrm{mg} \mathrm{CO} / 100 \mathrm{~g}$ of soil/24 h. Potential respiration (after addition of the readily available substrate - $10 \%$ glucose solution) was two or more times higher than the actual respiration. This indicates the deficiency of labile organic substances in the urbostratozems and the natural soil.

The highest value of $\mathrm{CO}_{2}$ emission per soil mass was found in the soil of industrial zone (sample 3), while the natural soil (sample 1) were characterized by the lowest intensity of respiration. The calculation of the biological activity per $1 \mathrm{~g}$ of carbon (Fig. 1) allows to specify the utilization of soil organic matter by microorganisms. The natural soil exhibited significantly higher activity than urbostratozems, which may indicate the presence of stable organic matter in these soils. Thus, as the anthropogenic impact increases, there is a tendency to a decrease in soil respiration rate. Other researchers also had shown significant reducing of soil respiration rates in metal-contaminated soils in comparison with unpolluted soils (Papa et al., 2010).

Bacteria and fungi diversity. The least number of microorganisms was found in the natural soil of the recreation zone (Oranienbaum Park, sample 1, Table 3). The number of fungi was similar in the soil of the recreational and industrial zones, while in the soil of the residential zone it was significantly lower. The maximum number of prokaryotes was found in the humus horizon of urbanozem of the residential
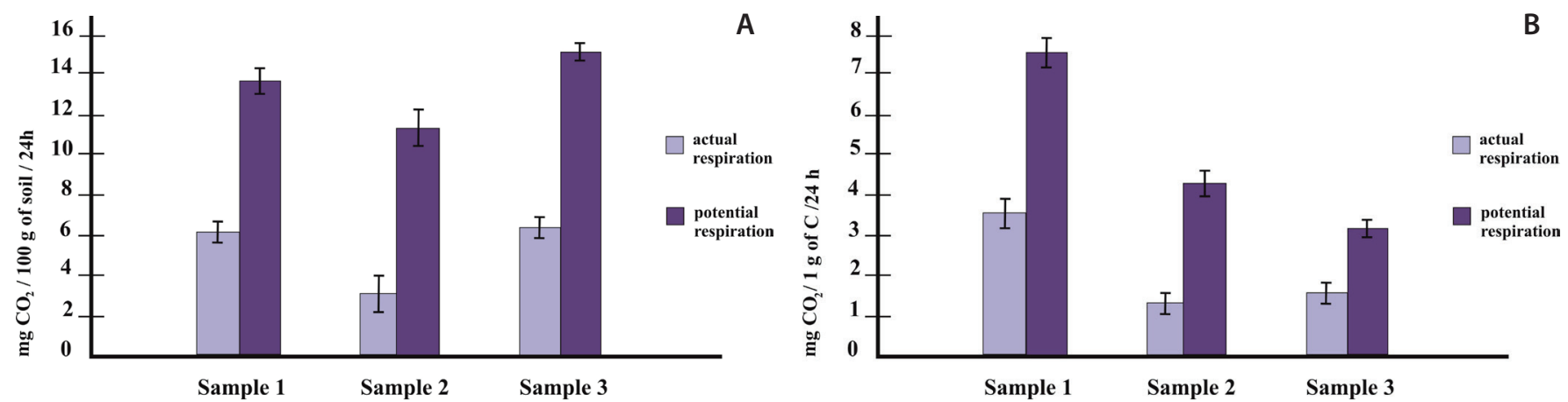

Fig. 1. Soil respiration rates (actual and potential): a $-\mathrm{mg} \mathrm{CO}_{2} / 100 \mathrm{~g}$ soil/24h; b $-\mathrm{mg} \mathrm{CO} / 1 \mathrm{~g} \mathrm{C} / 24 \mathrm{~h}$ 
zone (Polish Garden, sample 2). In the soil of the industrial zone (Elektrodepo, sample 3), the number of bacterial MCT was only slightly lower than in the soil of the residential zone. The neutral reaction of the soils, the high content of organic matter and the availability of mineral nutrition elements in the surface horizon of the urbostratozems contribute to active development of bacteria in these soils. Additionally, the stimulating effect of metals on soil microflora had been reported previously (Dai et al. 2004; Stefanowicz et al. 2012; Naylo et al. 2019).

In the upper horizon of the urbostratozem of the residential zone (sample 2), the diversity expands due to the appearance of MCT 3. At the same time, the structure of the bacterial cenosis also changes: if MCT 1 dominated in natural soil, MCT 2 dominated in the urbostratozem. In the ubostratozem (sample 2) MCT 1 and MCT 3 were subdominants, occupying positions of frequently encountered microorganisms. Frequency, abundance and high numbers indicate a relatively stable, though impoverished in the number of species cenosis.

Wide diversity and improvement of the structure of the bacterial cenosis in the urbostratozem of industrial zone (sample 3) compared with previous soils were observed. MCT 1 and MCT 2 were dominants. Also in this sample a significant number of rare and accidental MCTs were found, which characterizes this soil as the most favorable for the formation of wide diversity of bacteria.

The fungi were well adapted to the conditions of all the studied soils (Table 5). The structure of the fungal communities of the urbostratozems was close to each other and differed significantly from the natural soil due to the emergence of new MCT. Only MCT 2 and MCT 4 were common to all the studied soils. The most favorable structure of the fungal cenosis was observed in the humus horizon of the urbostratozem of the Polish Garden (sample 2). The horizon was characterized by a significant number of dominants, subdominants, and also rare species. The high fungal species diversity in urban soils was explained by the heterogeneity of their prop- erties (Marfenina et al. 2017). The higher diversity of bacterial and fungal communities in uban parks than in the forest was found by other researchers (Hui et al. 2017).

The soil of the industrial zone (sample 3 ) was characterized by a not very favorable structure of the fungal cenosis (the presence of one dominant and a small number of rare MCTs). There was a low diversity of fungi (the presence of two dominants and four subdominants) in the soddy podzol (sample 1).

Analysis of similarity coefficients (Table 6) showed that the greatest difference in the structure of the bacterial and fungal communities was observed between the natural soil of the recreational zone (sample 1) and the urbostratozem of the industrial zone (sample 3). Presumably, this is due to the fact that under the conditions of intense technogenic impact, new dominant MCT appeared. This phenomenon is consistent with conclusions of other researchers (Bityukova et al., 2016), which showed that in urbanozems species resistant to urban environmental conditions were predominate.

Algae are considered to be the most sensitive to anthropogenic effects. In polluted soils algal communities are degraded. The number and diversity of cenoses decreases, the presence of unicellular algae is characteristic (Zenova and Shtina 1991). In the studied soils, algae were found only in the soil of the Polish Garden where their number was 500 CFU/g of dry soil. The algae found there belong to the Ochrophyta and Chlorophyta, and are unicellular (Fig. 2). Algae were absent in the soddy podzol, likely as a result of a strongly acidic reaction of soil solution. The absence of algae in Electrodepo soil could be explained by the greater dryness of the soil and the more intense insolation of its surface. Indicator role of diatoms, which was shown in some publications (Dorokhova 2007), in our study was not revealed due to differences in the physicochemical characteristics of soils not related to pollution.

Enzymatic activity. The number of producers of the enzymes was determined for indirect assessment of the soil enzymatic activity (Table 7).

Table 3. The number of bacteria and fungi in the soils

\begin{tabular}{|c|c|c|}
\hline Sample & Bacteria, CFU* $10^{4} / \mathrm{g}$ of dry soil & Fungi, $C F U^{*} 10^{3} / \mathrm{g}$ of dry soil \\
\hline 1 & $15.4 \pm 5.65$ & $53.1 \pm 3.63$ \\
\hline 2 & $561.3 \pm 42.9$ & $9.0 \pm 2.9$ \\
\hline 3 & $312.2 \pm 24.0$ & $75.3 \pm 3.63$ \\
\hline
\end{tabular}

*CFU-colony-forming unit

Table 4. Structure of bacterial community in the soils

\begin{tabular}{|c|c|c|c|c|c|c|}
\hline \multirow{2}{*}{ MCT } & \multicolumn{2}{|c|}{ Sample 1 } & \multicolumn{2}{c|}{ Sample 2 } & \multicolumn{2}{c|}{ Sample 3 } \\
\cline { 2 - 7 } & Abundance, $\%$ & Frequency, $\%$ & Abundance, \% & Frequency, $\%$ & Abundance, \% & Frequency, \% \\
\hline 1 & 66.6 & 100 & 25 & 100 & 46.1 & 100 \\
\hline 2 & 33.3 & 50 & 50 & 100 & 42.3 & 100 \\
\hline 3 & 0 & 0 & 25 & 80 & 3.8 & 40 \\
\hline 4 & 0 & 0 & 0 & 0 & 2.56 & 80 \\
\hline 5 & 0 & 0 & 0 & 0 & 1.28 & 40 \\
\hline 6 & 0 & 0 & 0 & 0 & 2.56 & 40 \\
\hline 7 & 0 & 0 & 0 & 0 & 0.6 & 20 \\
\hline 8 & 0 & 0 & 0 & 0 & 0.6 & 20 \\
\hline
\end{tabular}


Table 5. Structure of fungi community in the soils

\begin{tabular}{|c|c|c|c|c|c|c|}
\hline \multirow{2}{*}{ MCT } & \multicolumn{2}{|c|}{ Sample 1} & \multicolumn{2}{|c|}{ Sample 2} & \multicolumn{2}{|c|}{ Sample 3} \\
\hline & Abundance, \% & Frequency, \% & Abundance, \% & Frequency, \% & Abundance, \% & Frequency, \% \\
\hline 1 & 12.5 & 33.3 & 3.7 & 33.3 & 0 & 0 \\
\hline 2 & 6.25 & 33.3 & 25.9 & 66.6 & 2.21 & 100 \\
\hline 3 & 6.25 & 33.3 & 0 & 0 & 0 & 0 \\
\hline 4 & 31.25 & 66.6 & 11.1 & 33.3 & 2.21 & 33.3 \\
\hline 5 & 37.5 & 66.6 & 3.7 & 33.3 & 0 & 0 \\
\hline 6 & 6.25 & 33.3 & 0 & 0 & 0 & 0 \\
\hline 7 & 0 & 0 & 14.81 & 100 & 0 & 0 \\
\hline 8 & 0 & 0 & 14.81 & 66.6 & 0 & 0 \\
\hline 9 & 0 & 0 & 14.81 & 66.6 & 0 & 0 \\
\hline 10 & 0 & 0 & 7.4 & 66.6 & 0 & 0 \\
\hline 11 & 0 & 0 & 3.7 & 33.3 & 3.53 & 66.6 \\
\hline 12 & 0 & 0 & 0 & 0 & 1.76 & 100 \\
\hline 13 & 0 & 0 & 0 & 0 & 90.2 & 100 \\
\hline
\end{tabular}

Table 6. Similarity coefficients of Sørensen for bacterial/fungal communities for the soils of different functional zones

\begin{tabular}{|c|c|c|c|}
\hline Samples & Sample 1 & Sample 2 & Sample 3 \\
\hline Sample 1 & - & $0.80 / 0.53$ & $0.40 / 0.36$ \\
\hline Sample 2 & $0.80 / 0.53$ & - & $0.54 / 0.43$ \\
\hline Sample 3 & $0.40 / 0.36$ & $0.54 / 0.43$ & - \\
\hline
\end{tabular}
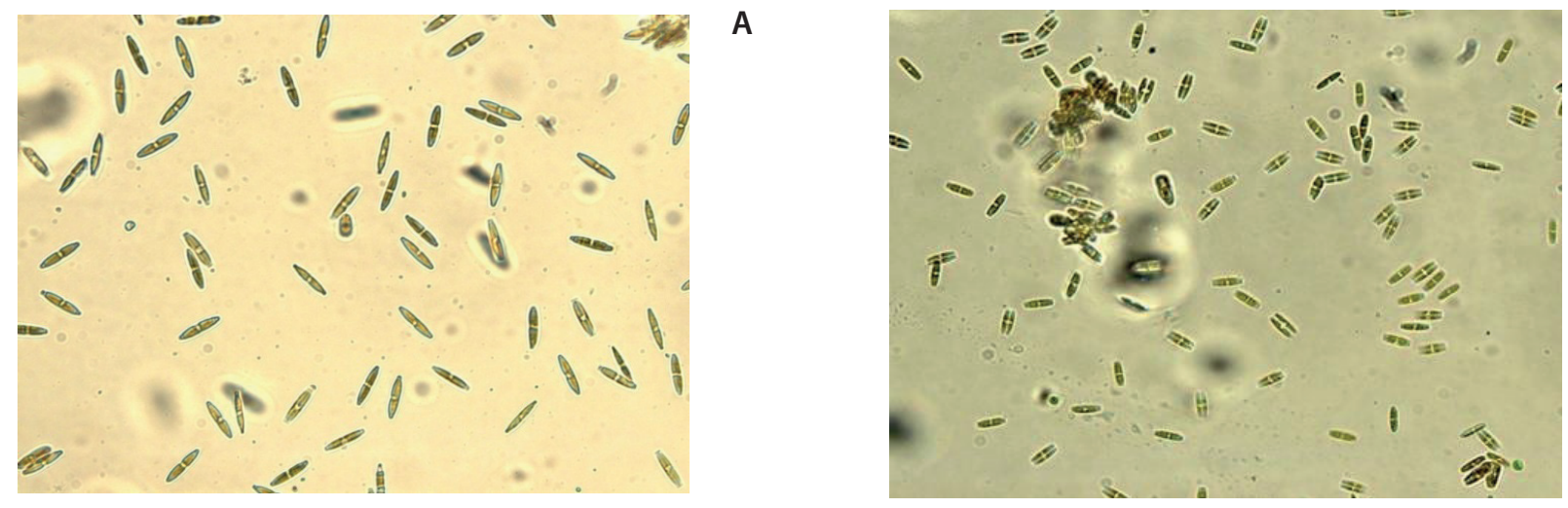

Fig. 2. Representatives of Ochrophyta algae in sample 2: a - Navicula Bory; b - Pinnularia Ehrenberg

Table 4. Structure of bacterial community in the soils

\begin{tabular}{|c|c|c|c|c|c|c|}
\hline $\begin{array}{l}\text { Number of enzyme } \\
\text { Droducers }\end{array}$ & \multicolumn{2}{|l|}{ Sample 1} & \multicolumn{2}{|l|}{ Sample 2} & \multicolumn{2}{|l|}{ Sample 3} \\
\hline & CFU* $10^{4} / \mathrm{g}$ of dry soil & $\%$ & $\mathrm{CFU}^{*} 10^{4} / \mathrm{g}$ of dry soil & $\%$ & CFU* $10^{4} / \mathrm{g}$ of dry soil & $\%$ \\
\hline Cellulase producers & $1.33+0.15$ & & $1.16+0.13$ & & $2.36+0.19$ & \\
\hline Lipase producers & $165.0+0.97$ & & $175.0+0.97$ & & $180.0+0.89$ & \\
\hline \multicolumn{7}{|l|}{ Protease producers } \\
\hline Active & $3.3+0.65$ & 11.1 & $56.6+2.61$ & 45.9 & $186.0+17.2$ & 74.6 \\
\hline Weak & $27.0+1.72$ & 88.9 & $66.6+2.35$ & 54.1 & $63.3+2.84$ & 25.4 \\
\hline \multicolumn{7}{|l|}{ Amilase producers } \\
\hline Very active & $16.6+1.30$ & 19.3 & $53.3+2.35$ & 37.2 & $14.3+1.73$ & 48.8 \\
\hline Active & $33.0+0.65$ & 3.8 & $36.6+0.65$ & 25.6 & $73.3+0.65$ & 25.0 \\
\hline Weak & $66.0+0.65$ & 76.9 & $53.3+1.13$ & 37.2 & $76.6+3.26$ & 26.2 \\
\hline
\end{tabular}




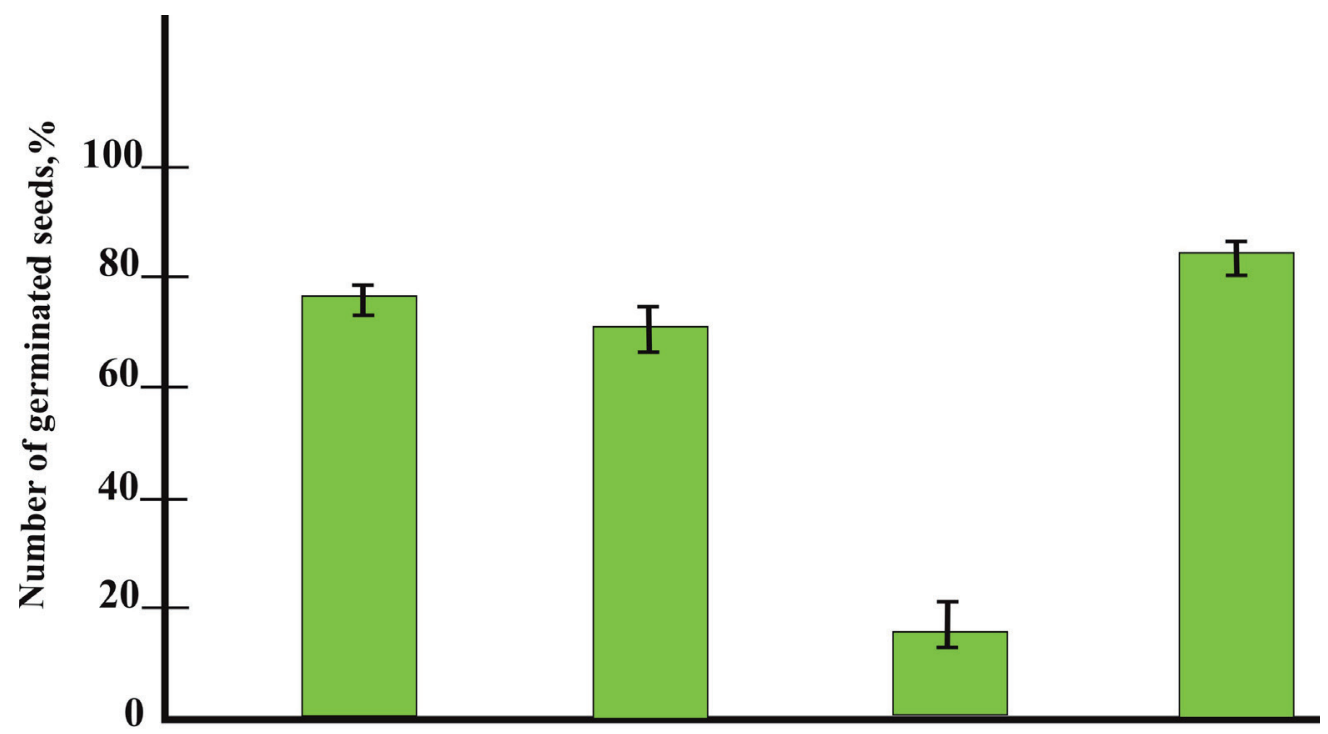

Sample 1 Sample 2 Sample 3 Control

Fig. 3. Assessment of phytotoxity: number of germinated seeds of cress in soil samples against control

Table 8. Medium length of roots and stems of cress on different soils

\begin{tabular}{|c|c|c|}
\hline Sample & Medium length of root, $\mathrm{mm}$ & Medium length of stem, $\mathrm{mm}$ \\
\hline 1 & $18.5+1.5$ & $3.5+0.5$ \\
\hline 2 & $5.0+0.5$ & $3.0+0.5$ \\
\hline 3 & $6.0+0.5$ & $2.0+0.5$ \\
\hline control & $25.0+3.5$ & $4.0+0.5$ \\
\hline
\end{tabular}

The minimum number of producers of all enzymes, except for cellulase, was observed in the soddy podzol in the recreational zone (sample 1) due to low concent of organic matter and acid $\mathrm{pH}$. Both characteristics are typical for natural soils of the region. The maximum number of protease and amylase producers was found in the soil of the industrial zone (sample 3). A significant number of microorganisms with high enzymatic activity in the soil of the industrial zone may be due to the fact that in this soil there is a maximum content of organic carbon, an optimal pH value and a high supply of nutrients (table 1), which is consistent with data on the determining role of these soil properties for microorganisms (Marfenina 2005). The soil of the residential zone (sample 2) was intermediate in enzymatic activity. Lipolytic activity was almost the same in all samples. Differences in the enzymatic activity of two urban soils can also be explained by differences in the structure of bacterial and fungal communities (table 5,6). The analysis of potential enzymatic activity confirmed our assumptions about a significant difference in the biological parameters of soils in different functional zones of the city.

Phytotoxity. The germination of cress (Lepidium sativum L.) seeds was used for assessment of the soil phytotoxicity. Seed germination, the average length of the root and the stem in the experiment compared with the control were choosen as the criteria for phytotoxicity. Seed germination was found to be the best indicator of phytotoxicity (Fig.3). Inhibition of seed development was observed in all soil samples studied, but the soil of the industrial zone was the most phytotoxic (sample 3) which was also consistent with our hypothesis. In addition to a 4-fold decrease in seed germination, a 5-fold decrease in the length of the root and a 2-fold decrease in the length of the stem were observed in this soil in comparison with the control (Table 8).

\section{CONCLUSIONS}

In this study, the urban soils of residential and industrial zones of Saint Petersburg were compared with the natural soil of recreational zone. The urban soils of residential and industrial zones differ from the natural soil by neutral and alkaline reaction and higher content of organic carbon. Both urban soils were polluted by heavy metals ( $\mathrm{Pb}, \mathrm{Cu}$ and $\mathrm{Zn}$ ). Heavy metal pollution was more pronounced in the soil of the industrial zone. The soil of the industrial zone differs in the structure of fungal and bacterial communities and in potential enzymatic activity from natural soil and from the soil of the residential zone as well. Contrary to the initial hypothesis about the negative effect of heavy metal pollution on soil microbiota, a greater number of morpho-cultural types of fungi and the highest number of microorganisms producing cellulase, amylase and protease were found in the soil of the industrial zone. Thus, assessment of the enzymatic activity of the soils by culturing of microorganisms-producers of protease, amylase, cellulase and lipase on special media used in the study was not sufficient to demonstrate the negative effect of the increased concentration of heavy metals in urban soils. However, in soils with a high content of heavy metals (Polish Garden and Electrodepo) a decrease in cress seed germination and a sharp reduction in the length of roots in cress seedlings were found. Therefore, phytotesting seems a promising and easy to use method for the comparative assessment of soils contaminated with heavy metals. The culture method used in our study did not allow to identify the response of the soil microbial community to heavy metal pollution. Therefore, it is necessary to use alternative methods to search for indicators of the activity and diversity of microorganisms in the environmental assessment of urban soils contaminated with heavy metals. 


\section{REFERENCES}

Aleksandrovskiy A., Dolgikh A. and Aleksandrovskaya E. (2012). Pedogenetic features of habitation deposits in ancient towns of European Russia and their alteration under different natural conditions. Boletin de la Sociedad Geologica Mexicana, 64(1), 71-77. DOI: 10.18268/ BSGM2012v64n1a6.

Bityukova V., Vlasov D., Dorokhova M., Kasimov N., Kislyakova N., Kirillov P., Kosheleva N., Nikiforova E., Petukhova N., Ryzhov A., Savoskul M., Saul'skaya T. and Shartova N. (2016). East - West of Moscow: a spatial analysis of social and environmental issues. Ed. by Kasimov N. Moscow: Faculty of Geography, Lomonosov Moscow State University.

Bouchez T., Blieux A., Dequiedt S., Domaizion I., Dufresne A., Ferreira S., Godon J., Hellal J., Joulian C., Quaiser A., Martin-Laurent F., Mauffret A., Monier J., Peyret P., Schmitt-Koplin P., Sibourg O., D'oiron E., Bispo A., Deportes I., Grand C., Cuny P., Maron P. and Ranjard L (2016). Molecular microbiology methods for environmental diagnosis. Environmental Chemistry Letters, 14, 423-441. DOI: 10.1007/s10311-016-0581-3.

Braun B., Böckelmann U., Grohmann E. and Szewzyk U. (2006). Polyphasic characterization of the bacterial community in an urban soil profile with in situ and culture-dependent methods. Applied Soil Ecology, 31, 267-279. DOl:10.1016/j.apsoil.200505.003.

Burghardt W., Morel J.and Zhang G.-L. (2015). Development of the soil research about urban, industrial, traffic, mining and military areas (SUITMA). Soil Science and Plant Nutrition, 61, supl. 1, 3-21. DOI: 10.1080/00380768.2015.1046136.

Calvarro L.M., de Santiago-Martin A., Gomez G.Q., Gonsallez-Huecas C., Quintana J.R., Vázquez A. et al. (2014). Biological activity in metal contaminated calcareous agricultural soils: the role of the organic matter composition and the particle size distribution. Environmental Science and Pollution Researche, 21(9), 6176-6187. DOI: 10.1007/s11356-014-2561-0.

Castaldi S., Butigliano F. andVirzo de Santo A. (2004) Suitability of soil microbial parameters as indicators of heavy metal pollution. Water, Air, and Soil Pollution, 158, 21-35. DOI: 10.1023/B:WATE.0000044824.88079.d9.

Charzynski P., Markiewicz M. and Switoniak M., eds. (2013). Technogenic soils atlas. Torun: Polish Society of Soil Science.

Classification System of Russian Soils (2004). Moscow: Pochv. Inst. im. Dokuchaeva. (in Russian).

Dai J., Becquer T., Rouiller J., Reversat G., Bernhardt-Reversat F. and Lavelle P. (2004). Influence of heavy metals on C and N mineralization and microbial biomass in Zn-Pb-Cu- and Cd-contaminated soils. Applied Soil Ecology, 2005, 99-109. DOI: 10.1016/j.apsoil.2003.09.003.

Dorokhova M. (2007) Diatoms as indicators of soil conditions in oil production regions. Oceanological and Hydrobiological Studies (Poland), 36, suppl.1, 129-135.

Hagmann D.F., Goodey N. M., Mathieu C., Evans J., Aronson M.F.J., Gallagher F. and Krumins J.A. (2015). Effect of metal contamination on microbial enzymatic activity in soil. Soil Biology and Biochemistry, 91, 291-297. DOI: 10.1016/j.soilbio.2015.09.012.

Huot H., Joyner J., Córdoba A., Shaw R., Wilson M., Walker R., Muth T. and Cheng Z. (2017). Characterizing urban soils in New York City: profile properties and bacterial communities. Journal of Soils and Sediments, 17, 393-407. DOI: 10.1007/s11368-016-1552-9.

Hui N., Jumpponen A., Francini G., Kotze D.J., Liu X., Romantschul M., Srömmer R. and Setal H. (2017). Soil microbial communities are shaped by vegetation type and park age in cities under cold climate. Environmental Microbiology 19(3), 1281-1295. DOl: 10.1111/1462-2920.13660.

Hygienic Standard 2.1.7.2042-06 (2006). Approximate permissible concentrations of chemical substances in soil. (in Russian).

Greinert A. (2015). The heterogeneity of urban soils in the light of their properties. Journal of Soils and Sediments, 15, 1725-1737. DOl: 10.1007/s11368-014-1054-6.

IUSS Working group WRB (2006). World reference base for soil resources. World Soil Recourses Reports № 103. FAO, Rome.

IUSS Working Group WRB (2014). World Reference Base for Soil Resources 2014. International soil classification system for naming soils and creating legends for soil maps. World Soil Resources Reports No. 106. FAO, Rome.

Ivashchenko K., Ananyeva N., Vasenev V., Sushko S., Seleznyova A. and Kudeyarov V. (2019). Microbial C-availability and organic matter decomposition in urban soils of megapolis depend on functional zoning. Soil Environ. 38(1), 31-41. DOI: 10.25252/SE/19/61524.

Labutova N.(2008). Methods of studing of soil microorganisms. SPb.: izd. SPbSU. (in Russian).

Labutova N. and Bankina T. (2013). Basics of soil enzymology. SPb.: izd. SPbSU. (in Russian).

Lehmann A. and Stahr K. (2007). Nature and significance of anthropogenic urban soils. Journal of Soils and Sediments, 7(4), 247-260. DOI: 10.1065/jss2007.06.235.

Marfenina O. (1987). Micromycetes as indicators of soil pollution by heavy metals. In: The influence of industry on environment. Moscow: Nauka, 189-196. (in Russian).

Marfenina O. (2005). Anthropogenic ecology of soil fungi. Moscow: Meditsina dlya vsekh. (in Russian).

Marfenina O., Lysak L., Ivanova A., Glushakova A., Kachalkin A., Nikolaeva V., Karlsen A. and Tepeeva A. (2017). Biodiversity in urban soils: threats and opportunities (on the example of cultivated microorganisms). Soils of Urban, Industrial, Traffic, Mining and Military Areas (SUITMA 9) 22-26 May 2017, Moscow. Abstracts, 109-111.

Matinian N.N., Reimann K., Bakhmatova K.A. and Rusakov A.V. (2007). The background concentration of heavy metals and As in arable soils of North-West of Russia (based on the materials of international geochemical atlas). Vestnik of Saint Petersburg state university, Seriya Biologia, 3, 123-134. (in Russian).

Microbiology laboratory manual (2005). Ed.: Netrusov A.l. Moscow: Academia publishing. 608 p. (in Russian).

Muchlbachova G., Sagova-Maeckova M., Omelka M., Szakova J. and Tlustos P. (2015). The influence of soil organic carbon on interactions between microbial parameters and metal concentrations at a long-term contaminated site. Science of the Total Environment, 502, 218-223. DOI: 10.1016/j.scitoenv.2014.08079.

Nannipieri P., Ascher J., Ceccherini M.T., Landi L., Pietramellara G. and Renella G. (2003). Microbial diversity and soil function. European Journal of Soil Science, 54, 655-670. DOI: 10.1046/j.1365-2389.2003.00556.x.

Naylo A., Almeida Pereira S.I., Benidire L., El Khalil H., Castro P.M.L., Ouvrard S., Schwartz C. and Boularbah A. (2019). Trace and major element contents, microbial communities, and enzymatic activities of urban soils of Marrakech city along an anthropization gradient. Journal of Soils and Sediments, 19, 2153-2165. DOI: 10.1007/s11368-018-2221-y.

Papa S., Bartoli G., Pellegrino A. and Fioretto A. (2010). Microbial activities and trace element contents in an urban soil. Environment Monitoring Assessment, 165, 193-203. DOI: 10.1017/s10661-009-0938-1.

Piotrowska-Dlugosz A. and Charzyńsky P. (2015). The impact of the soil sealing degree on microbial biomass, enzymatic activity, and physicochemical properties in the Ecranic Technosols of Toruń (Poland). Journal of Soils and Sediments, 15, 47-59. DOI: 10.1007/s11368-0140963-8. 
Prokof'eva, T., Gerasimova M., Bezuglova O., Bakhmatova K., Gol'eva A., Gorbov S., Zharikova E., Matinyan N., Nakvasina E. and Sivtseva N. (2014). Inclusion of soils and soil-like bodies of urban territories into the Russian soil classification system. Eurasian Soil Science, 47(10), 959-967. DOI: 10.7868/S0032180X14100104.

Prokof"eva T. and Poputnikov V. (2010). Anthropogenic transformation of soils in the Pokrovskoe-Streshnevo Park (Moscow) and adjacent residential areas, Eurasian Soil Science, 43 (6), 701-711. DOl: 10.1134/S1064229310060116.

Rabotnova I. and Pozmogova I. (1979). Chemostat cultivation and inhibition of microbial growth. M.: izd. Nauka. (in Russian).

Rozanova M., Prokof"eva T., Lysak L. and Rakhleeva A. (2016). Soil organic matter in the Moscow State University botanical garden on the Vorob'evy Hills. Eurasian Soil Science, 49 (9), 1013-1025. DOI: 10.1134/S106422931609012X.

Schindelbeck R., van Es H., Abawi G., Wolfe D., Whitlow T., Cugino B., Idowu O. and Moebius-Clune B. (2008). Comprehensive assessment of soil quality for landscape and urban management. Landscape and Urban Planning, 88, 73-80. DOI: 10.1016/j.landurbplan.2008.08.006.

Stefanovicz A., Kapusta P. and Szarek-Lukaszewska G. (2010). Pine forest and grassland differently influence the response of soil microbial communities to metal contamination. Science of the Total Environment, 408, 6134-6141. DOI: 10.1016/j.scitotenv.2010.08.056.

Stefanovicz A., Kapusta P., Szarek-Lukaszewska G., Groudzińska K., Niklińska M. and Vogt R.(2012). Soil fertility and plant diversity enhance microbial performance in metal-polluted soils. Science of the Total Environment, 439, 211-219. DOI: 10.1016/j.scitotenv.2012.09.030.

Szegi J. (1983). Methods of soil microbiology. Moscow: "Kolos" Publ. (in Russian).

Terekhova V., Pukalchik M. and Yakovlev A.(2014). The triad approach to ecological assessment of urban soils. Eurasian Soil Science, 47(9), 952-958. DOI: 10.1134/S1064229314090129.

Vorobieva L., ed. (2006). Theory and practice chemical analysis of soils. Moscow: izd. MGU. (in Russian).

Yuangen Y., Campbell C., Clark L., Cameron C. and Paterson E. (2006). Microbial indicators of heavy metal contamination in urban and rural soils. Chemosphere, 63, 1942-1952. DOI: 10.1016/j.chemosphere.2005.10.009.

Yuangen Y., Paterson E. and Campbell C. (2001). Urban soil microbial features and their environmental significance as exemplified by Aberdeen City, UK. Chinese Journal of Geochemistry, 20(1), 34-44. DOI: 10.1007/BF03166847.

Zenova G., Shtina E., Dedysh S.et al. (1995). Ecological connections of algae in biogeocoenoses. Microbiology, 64(2), 149-164. (in Russian). Zhigareva T., Ratnikov A., Sviridenko D., Popova G., Petrov K., Kas'yanenko A., Chernykh N. and Kartuzova M. (2006). Investigation of behavior of $\mathrm{Cd}$ and $\mathrm{Zn}$ and their influence on soil microbocenoces. Vestnik of RUDN. Ser. Ecology and life safety, 1(13), 34-40. (in Russian).

Zvyagintsev D., Bab'eva I. and Zenova G. (2005). Soil biology. Moscow: izd. MGU. (in Russian). 